\title{
The Democratic Practices of the Educational Leaders at the Hashemite University
}

Zuhair Hussain Al-Zoubi

Assistant Professor

Faculty of Educational Sciences

The Hashemite University, Jordan

Habes Hatamleh

Associate Professor

Faculty of Educational Sciences

Jadara University, Jordan

Mo'een Ahmad Oudat

Associate Professor

Faculty of Physical Education and Sport Sciences

The Hashemite University, Jordan

\section{Ibrahim Aed Algani Salameh}

Professor

Faculty of Physical Education and Sport Sciences

The Hashemite University, Jordan

\begin{abstract}
This study aimed to identify the democratic practices of the educational leaders in the Hashemite University, as viewed by the faculty members. The study sample consisted of (250) faculty members who were chosen by the stratified random method. The researchers developed an instrument to measure the reality of the democratic practices by the educational leaders at the Hashemite University, as viewed by the faculty members. The results showed that the reality of the democratic practices of the educational leaders at the Hashemite University, as viewed by the faculty members, was high. There were no statistically significant differences of this reality attributed to the gender and college variables. The results showed statistically significant differences of the democratic practices of the educational leaders at the Hashemite University, as viewed by the faculty members, attributed to the academic rank, as well as to the years of experience, in favor of those with more experience.
\end{abstract}

Keywords: Democratic Practices, Educational Leaders, Hashemite University.

\section{Introduction}

The democratic atmospheres form the ideal climate for building interactional educational relationships of positive attitudes. This is quite clear in the interactions of the dialogue, discussion, presenting the counterview, making positive criticism, freedom of discussion, criticism and critical thinking; as such climate is the premise and essence of the educational democracy. The democratic educational relations also form the basis of bestowal and creativity in its different shapes. This is a historical fact proven by the long experience of the human life. Science blooms and flourishes in democratic atmospheres, and the brain's giving was always tied to the freedom climates. Building on these facts, one can say that the creative presence of the mind, was always the product of the active presence of freedom and democracy (Ghazal and Maqableh 2013).

Universities, as higher education institutes, are a tool to provide the suitable conditions of the balanced intellectual, mind, emotional and social growth of their students, to be good citizens, capable to build the country through participation and collective responsibility (Fish 2007). The university is one of the pillars of the community's advancement and growth, as it works toward the development of the human resources with all specializations, and provides all the other institutions with human cadres required to the comprehensive development needs in the community (Abboud and Abdul Hameed 2000).The university plays a vital role in building and implanting the democratic values, and translating these values into practices on the real ground. This would be accomplished through the laws, instructions and different activities, which foster and contribute to laying the principle of dialogue; respect of the view and counterview; establishment of the values of justice, equality, freedom; and joint work and active participation. Further, this would be realized through finding leaderships able to accept responsibility (Reiger 2001). 
Moreover, the universities represent a symbol of the nation, its progress, awakening and civilization, as well as a substantial pivot rotating around the cultural life with its general and comprehensive meaning, and with its intellectual, literary, scientific and technological dimensions. In the campus, an elite of distinguished people gather, who have wealth of scientific research that will be generalized for the public service. In addition, every university has its unique structure, starting with its presidency coming down to its lowest level of services inside the university. Still, every university has its specialized faculties, each faculty has its dean, vice dean, dean assistant and head of department (Badarneh 2012).

Educational leaders (dean, vice dean, dean assistant and head of department) form a pivotal position of great importance in the higher education system; as about $80 \%$ of the university decisions are made at the academic department level(Gasem2007). The educational leader in the university hierarchy is the leader who attempts to convey the viewpoint of the department, and explains it to the management, on one hand, and conveys and explains the viewpoint of the management to the faculty members, on the other. This process is termed as "rotation", in which the educational leader is a median between the faculty members and the management or the academic institution. The academic departments are the hearts of the universities, and the key of their reputation and glory (Dykstra et al 2008). The largest portion of the higher education strength stems from the strengths of its academic departments. It is through these departments the colleges and universities succeed, and the strength of the university structure stems from its departments (Badarneh 2012). Jordan, through its civil society institutions, with the public universities being atop, seeks to exercise democracy prominently and keep a pace with the age dominated by cognitive, technological and scientific explosion. In the shade of the government interest in the development and modernization of the civil community responsibilities, the universities seek to translate this interest through dealing with the youth of all ages, according to a democratic method, to bring them up democratically (Moen et al 2010).

The human experiment, throughout its historical course, assures that democracy, particularly in the universities and other institutions concerned with the teaching and nonteaching aspects, and their integrity in the life of the nation, is an issue bonded with the rooting of the democratic values in the minds and emotionsof the people. Accordingly, educational democracy is one of the most sensitive and private cases of the age, due to the important social and political dimensions this case enfolds (Al-Amiareh and Maqableh2010).

Based on the foundations of democracy, with the belief that democracy is a way in life that includes all the human life aspects, both individually and collectively, the actual democratic practices of the educational leaders at the academic colleges will reflect on the commitment of the faculty members to the spirit of the system. Further, providing equal chances for all the workers will lead to the accomplishment and creativity of the faculty members, which will further be reflected on the progress and success of the abilities and capabilities of the faculty member, which, in turn, will reflect on the improvement of the educational leaders' functionality (Al-Jarrah 2013).

Many literatures explored the democratic practices applied by the faculty members and students through more than one perspective. that faculty members exercise democratic teaching in most of their studies. And the highest percentages in the democracy practice degree among the faculty members was that of the freedom of opinion and expression (AlOteibi, 2006; Rahmah, 2004). Al-Zboun (2011) pointed out that most of the democratic practices of faculty members. Affected by change of the geographic location and students' practices of the democratic principles and values.

\subsection{Problem and Questions of Study}

The problem of study is represented in identifying the factuality of the democratic practices of the educational leaders in the Hashemite University as viewed by the faculty members. This is per se due to the importance of the democracy phenomenon in the world in general, and in the education field in particular; due to the faculty members' discomfort, and failure of the educational leaders in the Hashemite University to practice the democratic method with their work colleagues, and through personal observations, and due to the future problems that may arise as a result, which will negatively, and, because of the feeling of unfairness, and misuse of the authority by leaders. The current study seeks to answer the following questions:

1- What is the reality of the democratic practices of the educational leaders in the Hashemite University, as viewed by the faculty members?

2-Are there statistically significant differences at $(\alpha \leq 0.05)$ level in the reality of the democratic practices of the educational leaders in the Hashemite University, as viewed by the faculty members, attributed to the variablesof (gender, college, academic degree, and years of experience)?

\subsection{Study Significance}

The significance of study originates from the broad interest in the democracy principles at the global level, in general, and Jordan level in particular. 
Many conferences, meetings, and political and educational orientations in Jordan concentrated on placing importance to such issues.It also originates from the great role performed by the educational institutions in preparing the democratic citizen who realizes the actual meaning of democracy, assimilates its principles and adheres to its ethics and practices. Therefore, it is hoped that this study will provide a beneficial tool to the researchers in the studies with subjects related to that of this study, and apply them in other environments.

\section{Methodology}

\subsection{Study Population and Sample}

The study population consisted of all the faculty members in the Hashemite University ( $\mathrm{N}=680)$, distributed over (18) colleges in the first semester of the university academic year 2017/2018. The study sample comprised (250) participants, who were chosen by the stratified random method, representing (37\%) of the original study population. Table (1) shows the distribution of the study sample participants over its variables.

Table 1:Distribution of the study sample by its variables

\begin{tabular}{|l|l|l|l|}
\hline Variable & Category & Frequencies & Percentage \\
\hline \multirow{3}{*}{ Gender } & Male & 210 & $84 \%$ \\
\cline { 2 - 4 } & Female & 40 & $16 \%$ \\
\hline \multirow{3}{*}{ Years of experience } & Scientific & 115 & $46 \%$ \\
\cline { 2 - 4 } & Humane & 135 & $54 \%$ \\
\hline \multirow{3}{*}{ Academic Degree } & 5 years and less & 60 & $24 \%$ \\
\cline { 2 - 4 } & $6-10$ years & 70 & $28 \%$ \\
\cline { 2 - 4 } & 11 years and more & 120 & $48 \%$ \\
\hline & Professor & 45 & $18 \%$ \\
\cline { 2 - 4 } & Associate Professor & 130 & $52 \%$ \\
\cline { 2 - 4 } & Assistant Professor & 75 & $30 \%$ \\
\hline
\end{tabular}

\subsection{Instrument}

The study instrument was developed based on the previous studies and research works reviewed by the researchers. It consisted of two sections. The first section included the variables (gender, college, years of experience and academic rank). The second section included (48) items distributed to four fields (Justice, (12) items; Responsibility, (12) items; Authority, (13) items; Privacy, (11) items).

\subsection{Instrument Validity}

To verify the study instrument validity, it was presented to (10) arbiters of specialized professors in both the University of Jordan and Al al-Bayt University. The final shape of the instrument was approved with (48) items, distributed over four fields, which were given graded weight according to Likert five-grade scale as follows: Very high (5 points), High (4 points), Medium (3 points), Low (2 points), and Very low (1 point).

\subsection{Instrument Reliability}

To ensure the reliability of the study instrument, (Test-Retest) method was employed. It was the relation between the first and second test using Pearson Correlation Coefficient (0.88). The coefficient of internal consistency was calculated using Cronbach's Alpha, table (2) illustrate that.

Table2:Reliability coefficient of the study instrument

\begin{tabular}{|l|l|l|}
\hline Field & Internal Consistency (Cronbach Alpha) & Test-Retest \\
\hline Justice & 0.91 & 0.84 \\
\hline Responsibility & 0.94 & 0.86 \\
\hline Authority & 0.98 & 0.89 \\
\hline Privacy Overall & 0.92 & 0.90 \\
\hline & 0.94 & 0.88 \\
\hline
\end{tabular}

\subsection{Procedures}

The study instrument was preparation, and verifying its validity and reliability, determining the population and sample, as well as obtaining the official approvals on the study procedures and methods.

To facilitate the researchers' duty in distributing the questionnaire over the sample participants during two months of the first semester of the academic year 2017/2018, they advised the sample participants about the objective of the study, 
the way to respond, and the confidentiality of the data they will provide, which will be exclusively for the purposes of scientific research.

\subsection{Statistical Analysis}

The researchers employed the frequencies and percentages for the characteristics of the study sample. They further used the means (M's) and standard deviations (SD's) in the statistical processing to obtain the study results, (T)-test, the One-Way Variance Analysis (ANOVA), and Scheffe test for the post hoc comparisons.

\section{Results and discussion}

3.1 Results of Question One: To answering this question, were calculated M's and SD's concerning the responses of the sample participants, table (3) illustrate that.

Table 3:The democratic practices in all fields

\begin{tabular}{|c|c|c|c|}
\hline Field & $\mathrm{M}$ & SD & Practice Level \\
\hline Responsibility & 3.83 & 1.01 & High \\
\hline Justice & 3.81 & 0.97 & High \\
\hline Authority & 3.71 & 1.02 & High \\
\hline Privacy & 3.70 & .098 & High \\
\hline Overall & 3.76 & 0.84 & High \\
\hline
\end{tabular}

Table (3) Shows that the educational leaders' democratic practices degree in the Hashemite University, as viewed by the faculty members, was high (3.76), on respectively. Responsibility (3.83); justice (3.81); authority (3.71); and privacy (3.70). This result is in line with (Al-Zboon 2011) that the organizations and institutions that work toward strengthening and deepening the democratic practices to maintain the human rights and freedom, face any possible breaches of the human rights, and ensure indiscrimination between the individuals on the grounds of language, gender, thought or religion. Universities are among the main and effective institutions that contribute in establishing and clarifying the principles of democracy, and developing the democratic practices that enable the individual turn into a social being, able to protect, and enhance the public freedoms, political and intellectual plurality, and secure respect of the human rights and dignity.To identify the estimations of the sample participants on each field of the four fields of the instrument, the M's and SD's of the participants' responses on every item of the instrument were calculated.

First Field: Justice

Table 4: The democratic practices in justice field

\begin{tabular}{|c|c|c|c|c|}
\hline No. & Items & $\mathrm{M}$ & SD & Practice Level \\
\hline 1 & $\begin{array}{l}\text { Provides his/her experiences in guiding the faculty members without } \\
\text { discrimination. }\end{array}$ & 4.07 & 0.90 & High \\
\hline 2 & Treats people justly regardless of the geographical regions. & 3.97 & 1.01 & High \\
\hline 3 & $\begin{array}{l}\text { Does not discriminate in dealing with the faculty members based on } \\
\text { their intellectual beliefs. }\end{array}$ & 3.94 & 0.98 & High \\
\hline 4 & $\begin{array}{l}\text { Applies justice among the faculty members regardless of their } \\
\text { academic degrees. }\end{array}$ & 3.87 & 0.95 & High \\
\hline 5 & $\begin{array}{l}\text { Treats all the people in the department equally as per the systems and } \\
\text { regulations of the University. }\end{array}$ & 3.86 & 0.97 & High \\
\hline 6 & $\begin{array}{l}\text { Fair in distributing the works of the department over the faculty } \\
\text { members. }\end{array}$ & 3.85 & 0.98 & High \\
\hline 7 & Fairly distributes the faculty members over the committees. & 3.83 & 1.01 & High \\
\hline 8 & $\begin{array}{l}\text { Does not discriminate in dealing with males and females of the } \\
\text { faculty members. }\end{array}$ & 3.81 & 1.09 & High \\
\hline 9 & $\begin{array}{l}\text { Distributes responsibilities fairly among the faculty members inside } \\
\text { the department. }\end{array}$ & 3.74 & 0.97 & High \\
\hline 10 & $\begin{array}{l}\text { Provides a psychological climate allowing free opinion of the faculty } \\
\text { members. }\end{array}$ & 3.64 & 1.05 & Medium \\
\hline 11 & Uses a democratic manner during the meetings. & 3.63 & 1.03 & Medium \\
\hline 12 & Provides guidance to all the faculty members. & 3.55 & 1.10 & Medium \\
\hline \multicolumn{2}{|r|}{ Overall } & 3.81 & 0.97 & High \\
\hline
\end{tabular}

Table (4) shows that the factuality of the democratic practices of the educational leaders in the Hashemite University, as viewed by the faculty members, on the field of "justice" was high. This result is in line with (Al-Oteibi 2006) that the 
universities play a vital and pivotal role in terms of building and planting the democratic values, and translating these values into practices on the actual ground through the laws, instructions, regulations and various activities, which support and contribute to laying the principle of dialogue and respect of the view and counterview.

They also contribute to the respect of values of fairness, equality, freedom, and mutual social work; in addition to the effective participation through providing leaders able to think freely and critically and accept responsibility.

Second Field: Responsibility

\section{Table 5:The democratic practices in responsibility field}

\begin{tabular}{|l|l|l|l|l|}
\hline No. & \multicolumn{1}{|c|}{ Items } & M & SD & Practice Level \\
\hline 13 & He/she is responsible for all the members of the department's council. & 4.17 & 0.86 & High \\
\hline 14 & Defends the faculty members in his/her department. & 4.04 & 0.88 & High \\
\hline 15 & $\begin{array}{l}\text { Accepts the responsibility of the decisions of the department's council } \\
\text { before the officials. }\end{array}$ & 4.03 & 0.91 & High \\
\hline 16 & $\begin{array}{l}\text { Shows the faculty members that it is quite necessary to adhere to the } \\
\text { lectures and office credit hours. }\end{array}$ & 4.02 & 0.81 & High \\
\hline 17 & Capable to take right decisions at the department level. & 3.98 & 0.98 & High \\
\hline 18 & Accepts responsibility of all the faculty members before the officials. & 3.91 & 1.28 & Medium \\
\hline 19 & Shows the faculty members the mistakes he/she makes. & 3.88 & 0.90 & High \\
\hline 20 & $\begin{array}{l}\text { Makes the faculty members feel that he/she is a member as the other } \\
\text { department council's members. }\end{array}$ & 3.79 & 1.00 & High \\
\hline 21 & $\begin{array}{l}\text { Guides the faculty members to adhere to the university systems and } \\
\text { regulations. }\end{array}$ & 3.63 & 1.21 & Medium \\
\hline 22 & Encourages the faculty members to carry out scientific research. & 3.51 & 1.28 & Medium \\
\hline 23 & Carries out the works assigned to him/her by the officials. & 3.50 & 1.26 & Medium \\
\hline 24 & Able to authorize administrative works to the department members. & 3.45 & 1.04 & Medium \\
\hline & Overall & 3.83 & 0.81 & High \\
\hline
\end{tabular}

Table (5) shows that the factuality of the democratic practices of the educational leaders in the Hashemite University, as viewed by the faculty members, on the field of responsibility was high. This result is in line with (Al-Jarrah, 2013) that the universities play a vital and pivotal role in terms of building and planting the democratic values, and translating these values into practices on the actual ground through the laws, instructions, regulations, which support and contribute to laying the principle of dialogue and respect of the view and counterview. They also contribute to the respect of values of fairness, equality, freedom, and mutual social work; in addition to the effective participation through providing leaders able to think freely and critically and accept responsibility.

Third Field: Authority

Table 6:The democratic practices in authority field

\begin{tabular}{|l|l|l|l|l|}
\hline No. & \multicolumn{1}{|c|}{ Items } & M & SD & Practice Level \\
\hline 25 & Accepts the views of the faculty members and their suggestions during the meetings & 4.26 & 0.78 & High \\
\hline 26 & $\begin{array}{l}\text { Utilizes his/her powers to interfere in the affairs of the committees inside the } \\
\text { department. }\end{array}$ & 3.99 & 0.90 & High \\
\hline 27 & Treats the faculty members in a democratic manner. & 3.89 & 0.83 & High \\
\hline 28 & Provides chance for the faculty members to choose the subjects they want to teach. & 3.87 & 1.00 & High \\
\hline 29 & $\begin{array}{l}\text { Uses his/her powers to direct the faculty members for writing scientific research works } \\
\text { for him. }\end{array}$ & 3.84 & 1.04 & High \\
\hline 30 & Utilizes his/her position to serve and develop the university. & 3.66 & 1.10 & Medium \\
\hline 31 & $\begin{array}{l}\text { Encourages multiple opinions about the discussion subject and dialogue in the } \\
\text { meetings. }\end{array}$ & 3.65 & 1.13 & Medium \\
\hline 32 & Treats the faculty members of the department in an authoritarian method. & 3.64 & 1.17 & Medium \\
\hline 33 & He/she insists on his/her opinion during the meetings. & 3.61 & 1.02 & Medium \\
\hline 34 & Uses multiple opinions about the discussion subject and dialogue in the meetings. & 3.60 & 1.03 & Medium \\
\hline 35 & Uses his/her powers to distribute the subjects over the faculty members. & 3.52 & 1.04 & Medium \\
\hline 36 & He/she utilizes his/her position for personal purposes. & 3.28 & 1.27 & Medium \\
\hline 37 & Utilizes his/her powers to interfere in the personal affairs of the faculty members. & 3.68 & 0.86 & Medium \\
\hline & \multicolumn{1}{|c|}{ Overall } & 3.71 & 1.02 & High \\
\hline
\end{tabular}


Table (6) shows that the factuality of the democratic practices of the educational leaders in the Hashemite University, as viewed by the faculty members, on the field of "authority" was high. This result is in line with (Harb 2007) that the democracy, in general, means the individuals' participation in the political system, and in setting the laws and systems, choosing the authority individuals within a pool of values and beliefs. Among these values are the principles of fairness, equality throughout all the community members, within the interest and care about the human rights that are universally recognized. Jordan is an example, which could be followed, within the Arab world in laying down the principles of democracy and guaranteeing the human rights. In this concern, a full section in the Jordanian constitution is devoted for the human rights, which specifies that all the Jordanians are equal before the law in all the rights and duties, no discrimination among them in the responsibilities and rights.

Fourth Field: Privacy

Table 7: The democratic practices in privacy field

\begin{tabular}{|l|l|l|l|l|}
\hline No. & \multicolumn{1}{|c|}{ Items } & M & SD & PracticeLevel \\
\hline 38 & Respects the privacy of the other sections inside the college. & 4.07 & 0.90 & High \\
\hline 39 & Respects the privacy of the faculty member with his/her students. & 4.02 & 0.81 & High \\
\hline 40 & $\begin{array}{l}\text { Observes the privacy of the faculty member when scheduling the meetings } \\
\text { of the department. }\end{array}$ & 3.83 & 1.01 & High \\
\hline 41 & Does not allow the college dean interfere in his/her department. & 3.71 & 1.11 & High \\
\hline 42 & Reserves the privacy of issues concerning the faculty members. & 3.70 & 1.12 & High \\
\hline 43 & Interferes in the course of the faculty members' lecture. & 3.69 & 1.14 & High \\
\hline 44 & Reveals the private issues of the faculty members. & 3.61 & 1.17 & Medium \\
\hline 45 & Shares the faculty members in his/her department their different occasions. & 3.58 & 1.22 & Medium \\
\hline 46 & $\begin{array}{l}\text { Does not allow presenting private issues of the faculty members in the } \\
\text { department. }\end{array}$ & 3.54 & 1.14 & Medium \\
\hline 47 & Interferes in the private issues of the faculty members. & 3.51 & 1.28 & Medium \\
\hline 48 & Interferes in the semester plan of the courses of the faculty members. & 3.46 & 1.17 & Medium \\
\hline
\end{tabular}

Table (7) shows that the factuality of the democratic practices of the educational leaders in the Hashemite University, as viewed by the faculty members, on the field of privacy was high. The results of this study agree with (Colnerud 2006; Al-Smadi and Al-Omari 2012). universities provide a climate and curricula that establish the principles and concepts of democracy, which are reflected on the democratic principles practice degree by the faculty members of the universities.

3.2 Question Two: Are there statistically significant differences at $(\alpha \leq 0.05)$ level in the reality of the democratic practices of the educational leaders in the Hashemite University, as viewed by the faculty members, attributed to the variables of (gender, college, academic degree or years of experience)?

\section{First: Gender}

The researchers calculated the means, standard deviations and $\mathrm{T}$ test results of the reality of the educational leaders' democratic practices in the Hashemite University as seen by the faculty members by the gender variable. Table (8) illustrate that.

Table 8:The reality of the educational leaders' democratic practices, by gender

\begin{tabular}{|l|l|l|l|l|l|l|}
\hline Variable & Gender & Participants & M & SD & T & Sign. \\
\hline \multirow{2}{*}{ Gender } & Male & 210 & 3.57 & 0.94 & 0.927 & 0.355 \\
\cline { 2 - 7 } & Female & 40 & 3.69 & 0.87 & & \\
\hline
\end{tabular}

Table (8) shows no statistically significant differences in the reality of the educational leaders' democratic practices in the Hashemite University, as viewed by the faculty members, attributable to the gender variables. This result is in line with (Al-Smadi and Al-Omari 2012) which did not show statistically significant differences in the democratic practices degree by the faculty members that could be ascribed to the gender variable.

\section{Second: The College}

The researchers calculated the means, standard deviations and $T$ test results of the reality of the educational leaders' democratic practices in the Hashemite University as seen by the faculty members, by the college variable. Table (9) illustrate that. 
Table 9: The reality of the educational leaders' democratic practices, bythe college

\begin{tabular}{|l|l|l|l|l|l|l|}
\hline Variable & College & Participants & M & SD & T & Sign. \\
\hline College & Scientific & 115 & 3.77 & 0.51 & 0.267 & 0.79 \\
\cline { 2 - 5 } & Humane & 135 & 3.80 & 0.77 & & \\
\hline
\end{tabular}

Table (9) shows that there are no statistically significant differences at $(\alpha \leq 0.05)$ level, in the level of the educational leaders' democratic practices in the Hashemite University by the college variable. In other words, the view of the faculty members in the Hashemite University about the educational leaders' democratic practices was not affected by the location of the faculty member by the college variable, whether in the scientific or humane colleges. The reason may be ascribed to that the faculty members, regardless of their gender, are all subject to application of the rules and regulations of the university. This result is in line with the results of the studies of (Brewer 2005; Al-Ashqar and AlLawh 2012). That the systems, rules and regulations provided that the faculty members have rights and required to perform duties included in these systems and regulations, which are applicable over all the faculty members.

\section{Third: Years of Experience}

To identify the differences in the responses of the sample participants, by the experience years' variable on the reality of the educational leaders' democratic practices, as viewed by the faculty members, the researchers calculated the M's and SD's, and applied the ANOVA analysis, Table (10) illustrate that.

Table 10:The reality of the educational leaders' democratic practices, by the years of experience

\begin{tabular}{|l|l|l|l|}
\hline Years of Experience & Participants & M & SD \\
\hline 5 years and less & 60 & 3.64 & 0.61 \\
\hline 6-10 years & 70 & 3.83 & 0.57 \\
\hline 11 years and more & 120 & 3.90 & 0.69 \\
\hline
\end{tabular}

Table (10). shows apparent differences of the reality of the academic leaders' practices of democracy in the Hashemite University, as viewed by the faculty members, by (years of experience). Table (11) illustrate that.

Table 11: ANOVA test by the years of experience

\begin{tabular}{|l|l|l|l|l|l|}
\hline Variance Source & Total Squares & Freedom Degree & Mean of the total Squares & F & Sign. \\
\hline Intergroup & 10.303 & 2 & 3.43 & 5.95 & 0.001 \\
\cline { 1 - 3 } Intragroup & 230.527 & 247 & 0.576 & & \\
\hline Total & 240.830 & 249 & & & \\
\hline
\end{tabular}

Statistically significant at $(\alpha \leq 0.05)$ level

Table (11) shows that statistically significant differences of the reality of the academic leaders' practices of democracy in the Hashemite University, as viewed by the faculty members, by years of experience variable. To determine the significance of these differences, Scheffe test for the post hoc comparisons. Table (12) illustrate that.

Table12:Scheffe test for post hoc comparisons by the years of experience

\begin{tabular}{|l|l|l|l|l|}
\hline Years of experience & M & 5 Years and less & From 6-10 Years & 11 Years and More \\
\hline 5 Years and Less & 3.64 & ------ & ----- & ------ \\
\hline From 5-10 Years & 3.82 & ----- & ----- & ----- \\
\hline 11 Years and More & 3.90 & 0.310 & 0.223 & \\
\hline
\end{tabular}

Table (12) showed statistically significant differences of the factuality of the democratic practices by the educational leaders in the Hashemite University, as viewed by the faculty members, which could be attributable to the years of experience, in favor of those with (11 years and more). This result could be interpreted by that the faculty member may gain an intellectual orientation in management over the years of experience in the field of teaching and dealing with the colleagues. The results of this question are in line with the results of the studies of (Al-Oteibi 2006; Mahjoub 2014).

\section{Fourth: The Academic Degree}

To identify the differences in the responses of the sample participants, by the academic degree variable, on the reality of the educational leaders' democratic practices, as viewed by the faculty members, the researchers calculated the M's and SD's, and applied the ANOVA analysis. 
Table 13: The reality of the educational leaders' democratic practices, by the academic degree

\begin{tabular}{|l|l|l|l|}
\hline Academic Degree & Participants & M & SD \\
\hline Professor & 45 & 3.73 & 0.60 \\
\hline Associate Professor & 130 & 3.66 & 0.65 \\
\hline Assistant Professor & 75 & 3.45 & 0.52 \\
\hline
\end{tabular}

Table (13) shows that statistically significant differences of the reality of the academic leaders' practices of democracy in the Hashemite University, as viewed by the faculty members, by academic degree variable. To determine the significance of these differences, ANOVA analysis was applied. Table (14) illustrates that.

Table14: ANOVA test by the academic degree

\begin{tabular}{|l|l|l|l|l|l|}
\hline Variance Source & Total Squares & Freedom Degree & Mean of the total Squares & F & Sign. \\
\hline Intergroup & 9.82 & 2 & 3.275 & 5.671 & 0.001 \\
\cline { 1 - 4 } Intragroup & 231.004 & 247 & 0.578 & & \\
\hline Total & 240.083 & 249 & & & \\
\hline
\end{tabular}

Statistically significant at $(\alpha \leq 0.05)$ level

Table (14) shows statistically significant differences of the reality of the academic leaders' practices of democracy in the Hashemite university, as viewed by the faculty members, attributed to the academic degree variable. To determine the significance of these differences, Scheffe test for post hoc comparisons was applied. Table (15) illustrate that.

Table 15: Scheffe test for post hoc comparisons by the academic degree

\begin{tabular}{|l|l|l|l|l|}
\hline Academic Degree & M & Professor & Associate Professor & Assistant Professor \\
\hline Professor & 3.73 & ------ & 0.430 & 0.392 \\
\hline Associate Professor & 3.66 & ----- & ----- & ----- \\
\hline Assistant Professor & 3.45 & ------ & ----- & ----- \\
\hline
\end{tabular}

Table (15) showed that statistically significant differences in the reality of the democratic practices by the educational leaders of the Hashemite University, as viewed by the faculty members, attributable to the academic degree, in favor of those of the "professor" rank. This result is in agreement with (Al-Ashqar and Al-Lawh 2012; Al-Jarrah 2013). When the faculty member in higher rank, and higher knowledge, and experience, development may occur in his/her view about the dealing manner with the faculty members, including administrative leaders.

Finally, democracy, in general, means the individuals' participation in the political system, and in setting the laws and systems, choosing the authority individuals within a pool of values and beliefs. Among these values are the principles of fairness, equality throughout all the community members, within the interest and care about the human rights that are universally recognized. Jordan is an example, which could be followed, within the Arab World in laying down the principles of democracy and guaranteeing the human rights. In this concern, a full section in the Jordanian constitution is devoted for the human rights, which specifies that all the Jordanians are equal before the law in all the rights and duties, no discrimination among them in the responsibilities and rights.

\section{Conclusions}

- The democratic practices degree in the Hashemite University from view of the faculty members was high.

- The universities have a vital role to build and plant the democratic values, and translating these values into practices on the actual ground through the laws, instructions, regulations and various activities, which support and contribute to laying the principle of dialogue and respect of the view.

- The results showed no statistically significant differences in the reality of the educational leaders' democratic practices in the Hashemite University, as viewed by the faculty members, attributable to the gender.

- The results showed statistically significant differences of the factuality of the democratic practices by the educational leaders in the Hashemite University, as viewed by the faculty members, which could be attributable to the years of experience, in favor 11 year and more.

- The results showed statistically significant differences in the reality of the democratic practices by the educational leaders of the Hashemite University, as viewed by the faculty members, attributable to the academic degree, in favor of those of the professor rank.

\section{Recommendations}

- Strengthening the democratic practices by the administrative leaders, through holding workshops, seminars, and dialogue sessions between the academic leaders and the faculty members. 
- Emphasis on the adherence to the ethics of the university profession, which make the university professor eligible and capable to hold the university mission.

- Conducting studies about the democratic practices with the faculty members of the Jordanian universities and their relation with the scientific productivity.

- Making survey studies about the modules of the democratic nature provided by the university as compulsory or elective courses, and showing the extent of their importance in rooting the academic freedom.

- Conducting a study about the democratic studies with the faculty members of the Jordanian universities, and their relations with the work life.

\section{Limitations of the Study}

Despite the fact that this study did find a significant relationship between of the educational leaders in the Hashemite University and the faculty members. The generalizability of the findings is limited and generalizations should not be made to other populations. This study involved only the faculty members in the Hashemite University. The responses of the participants were collected at one point of time using self-reported measures.

\section{References}

Al-Ashqar, Y. H.and Al-Lawh, E. H.2012. Human Relations Practice

Degree of the Faculty Member of Palestinian Universities, as Viewed by His/herStudents. Islamic University,Journal for Educational and Psychological Studies, 20(1): 405-435.

Abboud, A. and Abdul Hameed, J.2000. The University Management in the ArabWorld, Studies in the Comparative Education and Educational Management. Cairo, Egypt, Dar Al-Fikr Al-Arabi for Publishing.

Al-Amiareh, M. and Maqableh, A. 2010. Students' Evaluation of the Secondary School Role in Getting Them Gain the Democracy Culture and Their Behaviors, in the Light of the Democratic Change in the Jordanian Community, Al-Quds Open University Journal for Research and Studies, No. 21, 80-126.

Badarneh, M. 2012. Democracy Principles and Its Values Practice by the Postgraduate Students in the Jordanian Universities, and Ways of Their Development. Unpublished Ph.D. Dissertation, Al-Yarmouk University, Irbid.

Brewer, E. 2005. Professors Role in Motivating Students to Attend Class. Journal of Industrial Teacher Education, 42(3): 23-47.

Colnerud, G. 2006. Teacher Ethics as a Research Problem: Syntheses Achieved and New Issues, Teachers and New Issues, Teachers and Teaching: Theory and Practice 12(3): 365-385.

Dykstra, D. Moen, D.and Davies, T.2008. Student Perceptions of AppropriateClassroom Policies of College Professors, Journal of College Teaching and Learning, 5(4): 13-22.

Fish, S. 2007. Shard Governance: Democracy Is Not as Education Idea,Change, 39(2): 8-13.

Gasem, A. 2007. Higher Education Classroom Management: Kuwait University Students Views, The College Student Journal, 3(41): 573.

Ghazal, M. and Maqableh, N. 2013. Undesired Behaviors of the Faculty Members as Viewed by the Students of AlYarmouk University. An-Najah National University Journal for Research (Humane Studies), 27(3): 559-638.

Harb, R. A. 2007. Perceptions of An-Najah National University Students of the Democratic Practices of the Faculty Members in the University. MA Thesis, An-Najah National University, Palestine.

Al-Jarrah, W. 2013. Degree of the Democratic Values Practice with the Students and Faculty Members in the Jordanian Public Universities and Means of Activating Their Practices. Unpublished Ph.D. Dissertation, Al-Yarmouk University, Irbid.

Mahjoub, A. 2014. Perceptions of the General Diploma Students about the Democratic Practices of the Faculty Members in Al-Azhar University. Hebron University Journal for Research, B, 9(1): 113-141.

Moen, D. Davies,T.and Dykstra, D. T. 2010. A Comparison of Faculty and Student Perceptions Concerning Academic Freedom Protections, Proceeding of ASBBS, 18(1): 183-195.

Al-Oteibi, M. 2006. Democratic Practice Degree of the Faculty Members and Students of Kuwait University. Unpublished Ph.D. Dissertation, University of Jordan, Amman.

Rahma, A. H. 2004. Viewpoints of the Faculty Members and Students of Kuwait University on the University Teaching Democracy, Damascus University Journal for Educational Science, 20(2): 11-55.

Reiger, R. 2001. Graduating Seniors Make Democracy Become Alive by Evaluatingtheir High School Program Education (Chula Vista, Calif), 121(4) ,839-842.

Al-Smadi, R. and Al-Omari, A. 2012. The Jordanian Universities and Their Role in Enhancing the Democratic Practices among Their Students,Faculty of Education, Bahrain University. Educational and Psychological Sciences Journal,13(1): 217-240.

Al-Zboon, S. 2011. The Democratic Practices of the Faculty Members in Jarash Private University, as Viewed by Their Students. Dirassat:journal for Educational Sciences, University of Jordan, 2(38): 560-664. 